\title{
Language, Culture, and Early Childhood: Indigenous Children's Rights in a Time of Transformation
}

\author{
Margo Greenwood, \\ Academic Lead, NCCAH, Professor Education and First Nations Studies, \\ UNBC
}

\section{Introduction}

Article 30 of the United Nations Convention on the Rights of the Child (UNCRC) sets out the rights of Indigenous and minority children to learn about and practice their own culture, religion, and language in countries where these practices are not shared by the majority of the population. The provisions of Article 30 are particularly relevant in nations such as Canada that are built upon a history of colonization, where for generations Indigenous children have been dispossessed of their cultures, languages, territories, family and community ties - all of the foundational elements of healthy and whole Indigenous identities. The colonization of the life-worlds of Indigenous children represents, in short, a primary mechanism through which nations have attempted to eliminate and assimilate the Indigenous populations within their borders, with devastating multi-generational consequences for surviving Indigenous peoples.

It is not the intention of this article to recount the abuses of colonial power inflicted on Indigenous children throughout Canada's history of colonization - an ongoing process which is still impacting our children, the most vulnerable and valuable members of our nations. The abuses of colonization and the lasting repercussions for all members of our collectives have already been documented. Knowing that Indigenous peoples continue to face colonial legacies written across their territories, bodies, and lives with exceptional bravery and resilience rooted in Indigenous culture and knowledge, this article offers a hopeful view of the changing context in which we currently struggle for full realization of the rights of all Indigenous children. Although there is still far to go, there has perhaps never been more opportunity to realize the provisions of Article 30 in Canada than there is at this moment in history. 
This article outlines in the first section below the agreements and commitments that mark a new climate of reconciliation, healing, and relationship-building between the Government of Canada and First Nation, Métis, and Inuit peoples. The second section highlights why it is so important to take advantage of this new context of reconciliation and relationship-building in pushing for early childhood education and care that contributes to the revitalization of Indigenous knowledge, cultures, and languages. In this way, early childhood can be seen as a crucial site for reconciliation and cultural healing. The article closes by reflecting on some examples of early childhood programing that actualize the principles of Article 30, arguing that these successful programs can be used as models for a renewed system of care for young children rooted in Indigenous values and supported by Article 30 of the Convention on the Rights of the Child.

\section{Shifting ground, moving forward: Opportunities in an era of reconciliation}

One year after the release of the final report of the Truth and Reconciliation Commission (TRC) in 2015, former chair Senator Murray Sinclair was asked in a CBC interview what progress had been made on the commission's recommendations. While acknowledging that change is a slow process and some movement has been made on some fronts, Sinclair replied: "to suggest that there has been progress would be to suggest that we have achieved change, but we're just on the beginning edge of starting to change things" (Sinclair, cited in Mas, 2016).

Sinclair's measured response matches the sentiments of many Indigenous observers and advocates in Canada who for the past year have been closely watching and waiting to see how the newly-elected Liberal government and its charismatic leader, Prime Minister Justin Trudeau, would follow up on campaign promises to build a new relationship with Indigenous peoples in Canada. Among other things, the Liberal party's "Real Change" election platform included commitments to "a renewed, nation-to-nation relationship with Indigenous Peoples, based on recognition, rights, respect, co-operation, and partnership" (Liberal Party, n.d., n.p.), as well as closing the funding gap for First Nations education, providing new funding to help Indigenous communities promote and preserve their languages and cultures, following up on the recommendations of the TRC, launching an inquiry into missing and murdered Indigenous women and girls, and working with the Métis Nation to improve quality of life for Métis communities. Leaders of the Assembly of First Nations praised the Liberal government's first budget in May 2016 , which allocated $\$ 8.4$ billion towards Indigenous peoples over five years, stating that it was a "significant step in closing the gap in the quality of life between First 
Nations peoples and Canadians and beginning the process of reconciliation... [and] would [begin] to address decades of underfunding and neglect" (AFN, 2016, np).

Despite this, after just one year in office Trudeau's Liberal government has already been given a failing grade on efforts to make good on its campaign promises to Indigenous peoples (Macdonald, 2016). While it's tempting to throw our hands up in despair at another set of broken promises and disappointed expectations, there is another way to look at the situation - that is, to acknowledge that much, much more work needs to be done, and to be heartened by the fact that there has never before in history been as much attention and public pressure on the Canadian government to take meaningful action to substantially improve the life chances and living conditions for Indigenous peoples in Canada as there is at this moment. New conversations are emerging in public and private spheres that point to a cultural shift in mainstream Canadian society oriented toward increased awareness of the harms have been done to Indigenous peoples and the need for meaningful action to redress these harms.

One could mark the beginning of this shift with the Royal Commission on Aboriginal Peoples (RCAP), which concluded its work in 1996 after five years of investigation that focused on restoration of justice in relationships between Indigenous and non-Indigenous peoples in Canada. The Commission, which was struck in the year following the Oka Crisis in 1990, held 178 days of public hearings, visited 96 First Nation communities, consulted experts, commissioned research studies, and reviewed past inquiries and reports, ultimately presenting its findings in a document that analyzed "a relationship that has swung from partnership to domination, from mutual respect and co-operation to paternalism and attempted assimilation" (RCAP, 1996, n.p.). RCAP's central finding was that the policy of assimilation of Indigenous peoples - policies enacted by successive colonial governments in Canada that aimed to eliminate Indigenous peoples by absorbing them into mainstream Canadian society-were not only ethically and morally reprehensible, but they led to a multi-generational "legacy of brokenness" resulting from the removal of Indigenous peoples from their lands, suppression of their nationhood and systems of government, and stifling of their cultures and identities. Much of the damages were borne by Indigenous children subjected to the abuses of the Indian residential school system.

In order to redress the harm suffered by Indigenous peoples subjected to assimilation policies, the RCAP report recommended that new nation-to-nation relationships between Indigenous and non-Indigenous peoples in Canada be based on principles of recognition, respect, sharing, and responsibility, and grounded in new treaties that recognized Aboriginal peoples as self-governing nations. The Commission 
envisioned a "circle of well-being," in which self-government, economic self-reliance, partnerships of mutual respect with Canada, and healing would feed into one another, working towards the elimination of persistent inequities experienced by Indigenous individuals and communities in all facets of life. Although many of RCAP's recommendations seem as distant today as they did twenty years ago, RCAP represents a watershed moment in the history of Canada's colonial government and mainstream society - a moment in which Indigenous voices were heard and, even if not heeded, became a part of the public record of a nation starting to reckon with its ongoing and deeply harmful legacies of colonization.

The RCAP process ushered in a series of related moments working incrementally towards renewed relationships in a context of reconciliation. In 2006, the Indian Residential Schools Settlement Agreement (IRSSA), Canada's largest class action settlement to date, formally recognized the abuse of the Indian residential school system, and set out government commitments to compensate for the suffering and support the healing of survivors. The IRSSA also called for a formal and public apology for the abuses and trauma inflicted on Aboriginal children in residential schools, which the federal government delivered in 2008. Also in 2008, the government formed the Truth and Reconciliation Commission (TRC) to document the experiences of residential school survivors and their families. The final report of the TRC released in 2015 presented 94 "Calls to Action" divided into two categories: "legacy" actions (including child welfare, education, language and culture, health, and justice) aimed at redressing the harms resulting from the Indian residential school system, and "reconciliation" actions aimed at transforming the relationships between Indigenous and non-Indigenous peoples in Canada (TRC, 2015).

One of the top "reconciliation" actions of the TRC recommended that Canada fully endorse the United Nations Declaration on the Rights of Indigenous Peoples (UNDRIP). The UNDRIP was adopted in 2007 with the full support of 144 countries, 11 abstentions, and four countries voting against (Canada, US, Australia, and New Zealand). The US, Australia and New Zealand changed their vote in 2009 and Canada followed soon after in 2010, but with wording indicating that it viewed the Declaration as "aspirational," and not legally binding (CBC News, 2010). In 2016 the new federal government officially removed Canada's objector status and fully endorsed the UNDRIP, although it remains to be seen how the government of Canada will implement its new commitment to respecting the human rights of the Indigenous peoples living within its borders. 
Also in 2016, the Canadian Human Rights Tribunal released its ruling on a landmark case brought against the federal government by the Assembly of First Nations and the First Nations Child and Family Caring Society of Canada. The complaint filed in 2007 alleged that the government of Canada discriminates against First Nations children on reserve by providing less government child welfare funding than to other children in Canada (Blackstock, 2011). Despite concerted efforts on the part of the federal government to have the case dismissed on technical grounds, the Tribunal found that the federal government does discriminate against on-reserve First Nations children by providing up to $38 \%$ less funding than elsewhere in Canada (Fontaine, 2016). This landmark decision calls for redesign of Canada's child welfare system, increases to funding to support First Nations in developing and delivering their own child welfare, and recognition of the importance of culturally appropriate child welfare services. Although the federal government has been slow to respond to the Tribunal's orders, the ruling remains a significant source of pressure - and all indications show that this pressure will not be released until the government has made meaningful progress in fulfilling its obligations (APTN, 2016).

Granted, when one considers how little has changed in response to the commissions, inquiries, reports, and rulings described above, it sometimes seems like these herculean efforts have amounted to just the tiniest tip of an arrow-head - when what is needed is to pierce the heart of Canada's internalized and institutionalized domination of Indigenous peoples. But the work of dismantling these dysfunctional, dominating relationships and building new ones based on mutual respect and equity will require a resurgence of responsibility-based Indigenous communities with their own education, economic and political systems rooted everyday practices of Indigenous culture that are learned and experienced from birth (Corntassel, 2012). In this context, Article 30 of the UN Declaration of the Rights of the Child represents both a tangible international commitment and a national opportunity to push the government of Canada to ensure that every Indigenous child has the opportunity to live, learn, and enjoy their language, culture, and religion.

\section{Language, culture and identity: Good care for Indigenous children}

For Indigenous peoples, the care and education of children is a sacred and highly valued responsibility (Greenwood, 2009). Children are vital to the survival of Indigenous cultures because they are imbued with the ways of knowing and being of their collectives (Little Bear, 2000). The provisions of Article 30, which set out the right for Indigenous children to enjoy their language, culture, and spirituality, are crucial to the survival and 
resurgence of Indigenous peoples as a whole, not least because language is intimately tied to our identity as individuals and collectives. Thus, it is critically important to explore the connections between Indigenous languages, ways of knowing (epistemology), ways of being (ontology), and the values underlying relational accountability (axiology) (Wilson, 2001).

Although too much knowledge about the care and education of Indigenous children in traditional settings has bowed to the assimilation and erasure policies of colonization, much is being preserved by Indigenous individuals and groups, and documented by Indigenous scholars working in many different parts of the world (see Battiste \& Henderson, 2000; Chisholm, 1996; Goforth, 2003; Kawagley, 1995; Little Bear, 2000). As these and many other Indigenous scholars have pointed out, Indigenous knowledge is embedded, transmitted, and created in Indigenous languages (Battiste, 2002; Gardner, 2000; Williamson, 2000). In other words, Indigenous languages carry the world-views of Indigenous cultures and communities - world-views that are rooted in deep connections to the land. Henderson (2000a) writes that:

Aboriginal languages express an awareness of a local ecology and are directed to understanding both external life forms and the invisible forces beneath them, which Algonquin languages describe by the sounds mntu, manidoo, manito, manitu or Manitou. These words can be equated with the forces or essences of life or spirit, knowledge and thought. ... Aboriginal consciousness and language are structured according to Aboriginal people's understanding of the forces of the particular ecosystem in which they live. They derive most of the linguistic notions by which they describe the forces of an ecology from experience and from reflection on the forces of nature (pp. 262-263).

Indigenous languages are verb-oriented, acknowledging and respecting the constantly changing energy of the land. They are also primarily oral - the sound, meaning, and relationships conveyed in the spoken word relate the essence of Indigenous knowledge(s) in a way that the written word cannot.

Recognizing the crucial relationships between the orality of Indigenous languages and the embedded nature of the knowledges and world-views they convey is crucial for understanding the fuller implications of Article 30. The immersion of children in their language provides them with access to knowledge that helps define who they are in the context of their broader collectives. It also helps them construct their own knowledge as they interpret the world around them through the lens of their own cultures. Language is a keystone element in the good care of Indigenous children, and immersion provides access 
to knowledge built into the stories that demand understanding and participation as they transmit and teach Indigenous knowledge(s).

Stories and story-telling are a primary mode of knowledge-transmission in oral languages and cultures - stories are a "living history" that teach adults and children "who and what they are, where they come from, and how they are to interact with others, with natural things and with spirits" (Kawagley, 1995, p. 17). Story-telling is a crucial link between Elders and children, ensuring cultural continuity in the transmission of knowledge from generation to generation. Story-telling is cultural remembering, and stories can be seen as "mnemonic devices" that help us to remember history (Cohen, 2001; Holmes, 2000; Kawagley, 1995; Sterling, 2002; Storm, 1972). For Indigenous children, stories offer pathways not only to their Elders and family members, their history and knowledge(s) - they also lead ultimately to their identity as individuals and members of the collective. Storytellers play an essential role in Indigenous societies. Sterling (2002) describes the storyteller Yetko as a "tradition-bearer, the teacher of values and morals, and the entertainer" (p. 6) whose knowledge is passed through the generations. Archibald (1990) writes that "it was the magic of the storytelling skill that allowed the thoughts and meanings to meet and create new patterns of understanding; personal and communal knowledge found a meeting place with orality" (p. 77). Storytellers also have a responsibility to teach the morals and ethics that go along with knowledge (Battiste \& Henderson, 2000).

The care and education of children is a sacred responsibility for Indigenous people. Some traditions believe that each child brings with him/her a special gift, and others believe that children are the ancestors reborn (Little Bear, 2000; Joint First Nations/Inuit Federal Working Group, 1995; Native Council of Canada, 1990). Secwepemc Elder Mary Thomas teaches that the care of children begins from the time of conception:

When a young woman got pregnant, she was careful about what she ate and about the exercise she got. She drank a lot of good medicines, a lot of broth, and she did not overdo herself. The young Mother was also given the most attention-loving, caring attention. She wasn't allowed to see anything that was unpleasant, like spilled blood, a smashed finger, whatever. She wasn't allowed to go to a funeral where there was a lot of crying. She was only allowed to see nice things, like singing and dancing. The old people strongly believed that whatever happened to the young Mother also happened to her unborn child. (Personal communication, 1995) 
These beliefs, anchored in distinct Indigenous knowledge(s) and spirituality, direct adults and others to interact with children in ways that may differ from those in mainstream, Western, or secular notions of child care. Whereas at one time Indigenous children learned primarily from their families and communities (parents, grandparents, siblings, aunties and uncles, and community members), the school system and early childhood programs for young children have now taken over a large part of this role (Goforth, 2003). Most often, these formal systems of care and education perpetuate a philosophy and set of values about the world that is representative of the broader dominant society and not those of Indigenous or colonized peoples. Yet this is the contemporary and colonial present in which Indigenous peoples in Canada and many other Indigenous peoples around the globe find themselves.

In a summary about traditional Aboriginal life and the context in which children were raised, the Report of the Royal Commission on Aboriginal Peoples (RCAP), Vol. 3 (1996) offers this description:

Babies and toddlers spent their first years within the extended family where parents, grandparents, aunts and uncles, brothers and sisters all shared responsibility for protecting and nurturing them. Traditional Aboriginal childrearing practices permitted children to exert their will with little interference from adults. In this environment, children were encouraged to develop as thinking, autonomous beings. At the same time, they acquired language and were integrated into the rhythms of daily life in the family and community.

In this early stage of development, children learned how to interpret and respond to the world. They learned how to walk on the land, taking in the multiple cues needed to survive as hunters and gatherers; they were conditioned to see the primacy of relationships over material possessions; they discovered that they had special gifts that would define their place in and contribution to the family and community. From an early age, playing at the edge of adult work and social activities, they learned that dreams, visions and legends were as important to learning as practical instruction in how to build a boat or tan a hide. (pp. 446-47)

In this context of family and community, the primacy of relationships to Indigenous knowledge(s) is apparent. The importance of relationships (including how to develop and maintain them) is often one of the first Aboriginal teachings taught to children (Battiste \& Henderson, 2000; Henderson, 2000). Little Bear (2000) writes that "the function of Aboriginal values and customs is to maintain the relationships that hold creation together" (p. 81). Without relationships, the collective is fragmented and the 
interdependent ways that have ensured the survival of Indigenous communities is endangered. Survival of Indigenous knowledge(s) is dependent upon the interrelationships developed at the individual and collective levels. This learning of relationships and collective begins with the children and their teaching and learning.

\section{Honouring Indigenous children's rights: Early childhood programs with a focus on language development}

As noted in the previous section, today early childhood centres play a significant role in the care and education of many Indigenous children, who often spend the majority of their days outside their homes and collectives in systems of care not necessarily anchored in their ways of knowing and being. Considering the importance of language to Indigenous peoples and the role it plays in sustaining their epistemologies, early childhood programs can be sites of individual knowledge transmission and of collective cultural continuity. The collective nature of language adds a significant dimension to consider when implementing "language rights" for Indigenous children as articulated in Article 30. This dimension demands understanding the colonial relationship that exists between Indigenous and non-Indigenous peoples; it is a relationship that is necessarily political, social, cultural and historical, with all the complexities that go with those realities.

This section explores some examples of early childhood programs focusing on Indigenous languages. Some are total immersion programs (language nests) designed and controlled by Indigenous peoples, while others offer language as a part of a larger early childhood program or as stand-alone programs. In Canada, a patchwork of early childhood programs serving Indigenous children has emerged over the years. The diversity of these programs and services is in part dictated by the context in which the program is situated, by the degree of control Indigenous peoples have over the programs, or by the origin of the program itself.

In Canada, the mid 1990s saw the development of two key early childhood programs for Indigenous communities at a national level: the First Nations Inuit Child Care Initiative (FNICCI) and the Aboriginal Head Start (AHS) program. Both programs sought to provide early childhood programs and services for Indigenous children where previously there had been none. These programs emphasized the importance of language and culture to the children and communities they serve. Both programs are governmentfunded and as such are accountable to the funding agency and the program frameworks they implement. The FNICCI was developed by the Joint First Nations Inuit Federal 
Working Group, made up of Indigenous technical experts from across the country. The AHS program, on the other hand, was adopted from the highly successful United States program and adapted for Indigenous children, families and communities in Canada.

FNICCI and AHS programming demands engagement and participation of local Indigenous communities and consequent acknowledgement of the knowledge(s) held by Indigenous peoples. The development of the FNICCI was based on seven guiding principles: 1) First Nations and Inuit directed and controlled; 2) community based, holistic and focused on child development; 3) quality services including the culture, language and values of the people being served; 4) inclusive, comprehensive and flexible; 5) accessible; 6) accountable; and 7) affordable (Greenwood, 2009). Both programs promote the cultural, spiritual, physical and emotional development of each child and community. They encompass traditional cultural practices and a holistic approach to learning and early development, which empowers children and strengthens their pride in themselves and their community. While not total language immersion programs, both programs offer opportunities for Indigenous children to engage with their language and their culture. At the core of these programs are values centred on involving community, acknowledging diverse systems of knowledge and facilitating individual and collective learning - all of which lay the groundwork for realizing the provisions of Article 30 for Indigenous children.

Language nest programs are Indigenous cultural early childhood language immersion programs where young children can learn the language through meaningful interaction with proficient speakers. Language immersion programs are considered to be the most successful way of reviving languages (McIvor, 2006). This approach involves teaching an Indigenous language in the early childhood program by only using that Indigenous language without any use of English. The concept of the language nest originated in New Zealand in the early 1980s as a part of Maori language revitalization and has served as a model for other countries, including Canada. Some First Nations communities in B.C. have been working towards creating language nests. One example can be found in the Splatsin First Nation near Enderby, B.C., where the Splatsin Tsm7aksaltn (Splatsin Teaching Centre) Society offers early childhood education based on language revitalization efforts reaching back to the 1970s, including a program which brings grandmothers and Elders into the program to teach young children the Splatsin language (Splatisn Tsm7aksaltn, n.d.). Other examples in B.C. include the Adam's Lake Band in south-central BC and the Lil'wat Nation (formerly known as Mount Currie). These programs are situated in community and focus on the local language and culture. While they may be funded externally, the programming and pedagogy is anchored in the 
ways of the community and is accountable for the transmission of the specific cultural and linguistic knowledge.

Language nests (known in Maori as Kohanga reo) in Aotearoa New Zealand have a long history of being anchored in community and originating from the people. In the late 1970s, a series of conferences held by the Department of Maori Affairs focused on concerns that the Maori language was nearing extinction (Smith, 1987; Tangaere, 1997). The Kaumaatua (Elders) articulated the following principle: "The language is the life principle of the Maori mana [spirit, pride]" (Fleras, 1983; Te Kohanga Reo National Trust Board, 1995). The centrality of this principle to Maori mana necessitated that Maori people "take control of the future destiny of the language and to plan for its survival" (Government Review Team, 1988, p. 18, quoted in Tangaere, 1997, p. 6). In response, the New Zealand government sponsored a preschool pilot project in Wainuiomata, located close to Wellington, which became the first official Kohanga reo. The success of the pilot quickly spread throughout the country, leading to the establishment of 54 programs by the end of the calendar year (Fleras, 1983) and over 600 within the next seven years (Tangaere, 1997). These programs received very little funding. In fact, their success has been attributed to "the dedication of a small team within the Te Kohanga Reo National Trust and the personal commitment that the Maori people gave through voluntary assistance and aroha" (Tangaere, 1997, p. 6). Each program is implemented differently, given local interpretation of the broad policies and how best to implement them for their children. This understanding appears to have been expressed from the onset of the development of Te Kohanga Reo movement by both the Maori community as well as the government. In short, the Kohanga reo are developed by the people for the people, with control in the hands of the families and communities which create, govern and administer language nests for their own children.

\section{Conclusion}

Article 30 is critical to Indigenous children around the world insofar as it enshrines their rights to enjoy their languages and cultures, preserving and supporting the core of their identity development and cultural continuity in national contexts where they are in the minority. Above all, Article 30 acts as a stimulus for states to meaningfully acknowledge the importance and support actions to preserve and revitalize threatened Indigenous languages and cultures. This is especially important for nation-to-nation relationships in colonial countries around the globe. 
In Canada, our emerging patchwork of local, regional, and national programs reflects the diversity of Indigenous traditions from coast to coast to coast. However, concerted efforts to analyze, understand, and maintain a commitment to the provisions of Article 30 are necessary across the diversity of government-funded and community-based programs. The experiences of the Kohanga reo in Aotearoa New Zealand are instructive in this regard - each program has been developed based on a commitment to the Maori language and the specific epistemologies and ontologies of the communities and families involved in developing programs for their own children. In this way, the process and content for developing early childhood programs focused on culture and language are rooted in local needs, knowledge, and ways of being.

In Canada, we are in a time of significant transformation. It is time to take stock of our strengths and weakness and build on those strengths to create the changes needed for Indigenous children and their nations to take their rightful place in Canada. Assimilative government policies have undermined the hearts of our communities for generations, and so we must go back to our original knowledge in order to rebuild our nations through our own languages and ways of knowing and being in the world. It is time for Canadian government and society to recognize that other knowledge systems and cultures pre-exist the Western knowledge(s) brought with the newcomers to our territories. Living in a relationship of harmony and balance, as articulated in the treaties, means that current relationships between Indigenous and non-Indigenous peoples must be transformed, not only for today, but also for those generations coming behind us. These transformations must happen at all levels of governance, administration and implementation, for all ages and at all times. Indigenous knowledge tells us that we are in the time of the $7^{\text {th }}$ fire, a time of action. It is our collective responsibility to engage this time of change and opportunity in Canada, to change today and to set the foundation for tomorrow. 
Canadian Journal of Children's Rights Vol. 3, No. 1, 2016

\section{References}

Assembly of First Nations (AFN). (2016, March 22). AFN national chief says federal budget a significant step in closing the gap for First Nations. Press release. Retrived from http://www.afn.ca/en/news-media/latest-news/16-3-22-afnnational-chief-says-federal-budget-a-significant-step-in-c

APTN. (2016, September 15). Tribunal orders Canada, again, to comply with its ruling on First Nation child welfare. APTN News. Retrieved from http://aptn.ca/news/2016/09/15/tribunal-orders-canada-again-to-comply-with-itsruling-on-first-nation-child-welfare/

Archibald, J. (1990). Coyote's story about orality and literacy: Using two pairs of eyes. Canadian Journal of Native Education, 17(2), 66-81.

Battiste, M. (2002). Indigenous knowledge and pedagogy in First Nations education: A literature review with recommendations. Retrieved August 7, 2003, from http://www.ainc-inac.gc.ca/pr/pub/krw/ikp_e.html

Battiste, M., \& Henderson, J. (2000). Protecting Indigenous knowledge and heritage: A global challenge. Saskatoon, SK: Purich Publishing.

Blackstock, C. (2011). The Canadian Human Rights Tribunal on First Nations child welfare: Why if Canada wins, equality and justice lose. Children and Youth Services Review, 33(1), 187-194.

Chisholm, J. (1996). Learning "respect for everything": Navajo images of development. In C.P. Hwang, M. Lamb, \& I. Sigel (Eds.), Images of childhood. (pp. 167-183). Mahwah, NJ: Lawrence Erlbaum Associates, Inc.

Corntassel, J. (2012). Re-envisioning resurgence: Indigenous pathways to decolonization and sustainable self-determination. Decolonization: Indigeneity, Education \& Society, 1(1).

CBC News. 2010, November 12. Canada endorses indigenous rights declaration. CBC News online. http://www.cbc.ca/news/canada/canada-endorses-indigenous-rightsdeclaration-1.964779 
Education Review Office (ERO), Ministry of Education. (2005). Evaluation Indicators for Kohanga Reo. Wellington, NZ: Ministry of Education.

Fleras, T.A. (1983). Te Kohanga Reo preparation for life - Preparation for school. A preliminary report on the organization, objectives and implications of Maori language nests presented to the Department of Maori Affairs. Waterloo, ON: University of Waterloo.

Fontaine, T. (2016, January 26). Canada discriminates against children on reserves, tribunal rules. $C B C$ News. Retrieved from http://www.cbc.ca/news/indigenous/canada-discriminates-against-children-onreserves-tribunal-rules-1.3419480

Gardner, E. (2000). Where there are always wild strawberries. Canadian Journal of Native Education, 24(1), 7-13.

Goforth, S. (2003). Traditional parenting skills in contemporary life. Healing Words, $4(1), 17-19$.

Greenwood, M. (2009). Places for the good care of children: A discussion of Indigenous cultural considerations and early childhood in Canada and New Zealand. Vancouver, BC: University of British Columbia, Faculty of Education.

Henderson, J. (2000). Ayukpachi: Empowering Aboriginal thought. In M. Battiste (Ed.), Reclaiming Indigenous voice and vision (pp. 248-278). Vancouver, BC: UBC Press.

Kawagley, O. (1995). A Yupiaq Worldview: A pathway to ecology and spirit. Prospect Heights, IL: Waveland Press.

Liberal Party of Canada. (n.d.) Explore the platform. Retrieved from https://www.liberal.ca/realchange/

Little Bear, L. (2000). Jagged worldviews colliding. In M. Battiste (Ed.), Reclaiming Indigenous voice and vision (pp. 77-85). Vancouver, BC: UBC Press.

Macdonald, N. (2016, October 16). The Liberals' relationship with Indigenous communities sours. Macleans. Retrieved from 
Canadian Journal of Children's Rights Vol. 3, No. 1, 2016

http://www.macleans.ca/politics/liberals-relationship-with-indigenouscommunities-sours/

Mas, S. (2016, June 2). 1 year after Truth and Reconciliation report: 'Not seeing change yet.' CBC News. Retrieved from http://www.cbc.ca/news/politics/truth-andreconciliation-murray-sinclair-1.3611110

Mayfield, M.I. (1982). Native Infant Program: Evaluation Report III. Paper presented at the Annual Meeting of the National Association for the Education of Young Children, Washington, DC, November 11-14.

McIvor, O. (2006). Language nest programs in BC. http://www.fpcc.ca/files/pdf/language-nest-programs in bc.pdf

McIvor, O. (2005). Building the nests: Indigenous language revitalization in Canada through early childhood immersion programs. Victoria, BC: UVic Master of Arts thesis.

https://dspace.library.uvic.ca:8443/bitstream/handle/1828/686/mcivor_c2005.pdf? sequence $=1$;

McIvor, O., \& Parker, A. (2015). Back to the future: Recreating natural Indigenous language learning environments through language nest early childhood immersion programs. The International Journal of Holistic Early Learning and Development, 3: 20-35.

Royal Commission on Aboriginal Peoples. (1996). Report of the Royal Commission on AboriginalPeoples, Ottawa, ON. Government of Canada, Minister of Supply and Services.

Smith, G.H. (1987, January). Akonga Maori A discussion paper of culturally preferred learning and teaching methodologies as used with Te Kohanga Reo and related educational issues. Auckland, NZ: Auckland College of Education.

Splatisn Tsm7aksaltn (n.d.). Splatsin Tsm7aksaltn Society. Retrieved from http://www.splatsin.org/

Tangaere, A.R. (1997). Learning Maori together: Kohanga Reo and home. Wellington, NZ: New Zealand Council for Education Research. 
Te Kohanga Reo National Trust Board. (2003). Structure; history. Te Kohanga Reo National Trust: ko te reo te mauri o te mana maori. Retrieved June, 2005, from http://www.kohanga.ac.nz/structure.html

Te Kohanga Reo National Trust Board. (1995). Te Korowai. Wellington, NZ: Author.

Truth and Reconciliation Commission (TRC). (2015). Honouring the Truth, Reconciling for the Future: Summary of the Final Report of the Truth and Reconciliation Commission of Canada. Retrieved from http://www.trc.ca/websites/trcinstitution/File/2015/Honouring the Truth_Reconc iling for the Future July 23 2015.pdf

Williamson, K. (2000). Celestial and social families of the Inuit. In R.F. Laliberte, P. Settee, J.B. Waldram, R. Innes, B. MacDougall, L. McBain, \& L. Barron (Eds.), Expressions in Canadian Native studies (pp.125-146). Saskatoon, SK: University Extension, University of Saskatchewan.

Wilson, S. (2001). What is an indigenous research methodology? Canadian journal of native education, 25(2), 175-179. 